\title{
BCCT learning management: Islamic education's material in early childhood
}

\author{
Nur Hasanah \\ IAIN Salatiga \\ nurhasanah201157@yahoo.com \\ DOI: 10.18326/mudarrisa.v9i1.28-52
}

\begin{abstract}
This research is aimed to know the BBCT (Beyond Center and Circle Time) learning management on Early Childhood Islamic Education' Material in BCC (Bina Citra Cendekia) Ungaran Kindergarten and to know the supporting and unsupporting management factors of Early Childhood Islamic Education' Material in BCC Ungaran Kindergarten. This research belongs to qualitative research which focuses on the BBCT learning management of Early Childhood Islamic Education' Material in BCC Ungaran Kindergarten.The subject of this research is the principal and teachers. The method of collecting data is observation, interview, and documentation. And data analysis technique used in this research is inductive analysis method.The results of this research show that BBCT learning management on Early Childhood Islamic Education' Material in BCC Ungaran Kindergarten is good, because it based on the regulation from Permendiknas (Regulation from the Ministry of Education Affairs of Indonesia) No. 58 Year 2009 of standard contents and evaluation, include: planning, actuating, and learning evaluation. The supporting factors of the BCCT learning management are facilities, such as: buildings, classrooms, teachers' rooms, giving reward for the best achievement teachers (the funding comes from the institution); BCCT training for one week in Istiqlal, Jakarta. Then, unsupporting factors of BCCT learning management are the limited media of learning and the number of teachers, so that the learning process is still not maximal. Supporting games are limited too, so students do not have options to play with.
\end{abstract}


Keywords: BCCT Learning Management, Islamic education, early childhood education

\begin{abstract}
Abstrak
Penelitian ditujukan untuk mengetahui manajemen pembelajaran BCCT (Beyond Center and Circle Time) materi Pendidikan Agama Islam pada anak usia dini di TK BCC (Bina Citra Cendekia) Ungaran serta mengetahui faktor pendukung dan penghambat manajemen pembelajaran BCCT materi Pendidikan Agama Islam pada anak usia dini di TK BCC Ungaran. Penelitian ini termasuk penelitian kualitatif yang fokus studinya pada manajemen pembelajaran BCCT materi Pendidikan Agama Islam pada anak usia dini di TK BCC Ungaran. Subyek penelitiannya adalah Kepala sekolah dan guru. Metode pengumpulan data adalah observasi, wawancara, dan dokumentasi. Dan teknik analisis datanya adalah teknik analisis induktif. Hasil temuan penelitiannya menunjukkan bahwa manajemen pembelajaran BCCT materi Pendidikan Agama Islam anak usia dini di Tk BCC Ungaran sudah baik karena sesuai dengan peraturan Permendiknas No. 58 Tahun 2009 tentang standar isi dan penilaian yang meliputi: perencanaan, pelaksanaan, dan evaluasi pembelajaran. Faktor pendukung manajemen pembelajaran BCCT adalah sarana dan prasarana seperti: gedung, ruang kelas, ruang guru, jenis-jenis sentra serta pemberian reward bagi guru yang berprestasi dari lembaga yaitu pelatihan pembelajaran BCCT selama 1 minggu di Istiqlal Jakarta. Sedangkan faktor penghambat manajemen pembelajaran BCCT adalah jumlah guru dan media pembelajaran yang terbatas sehingga pembelajaran kurang maksimal, dan keterbatasan permainan pada setiap pijakan sehingga anak didik tidak banyak mempunyai pilihan dalam permainan yang dinginkan.
\end{abstract}

Kata kunci: manajemen pembelajaran BCCT, pendidikan Islam, pendidikan anak usia dini

\title{
Introduction
}

Early childhood or pre-school period is the golden age to develop the potentiality and intelligence of children. This period is a unique process 
of development and growth. Children have development process, giving idea, creating, language and communication based on their development and growth steps.

In this early childhood period, the growth process is fast and vey busy. So, kindergarten becomes the strategic institution to gain religious education for children, in order to be obedient children, good behavior, and respect to Islamic regulation which is taught for them (Otib, Hidayat, 2000: 73). Not every parent can understand to teach her children. So, children need good environment to develop their overall potentiality.

In UU Sisdiknas (regulation of national education system) states that the foundation of early childhood education is optimalization of development and elaboration effort through all potentialities which are directed to the children age 0-6 years old by giving education stimulation to help their physical and spiritual' growth in order to continue their next education. The stimulation above includes spiritual, emotional, social, cognitive and pshycomotoric aspect. Those are the essential foundation for early childhood education which have to be tied by some stimulated knowledge.

In the early childhood education's curriculum which is integrated by Islamic values is familiar by the term manhaj; it means the light way passed by teachers and their students to develop knowledge, skills and their attitudes (cognitive, affective and pshycomotoric) based on alQur'an and hadith as the essential foundation to conduct Islamic education. So, to ease children accepting stimulation from many educational aspects in order to conduct the Islamic education, they need 
precise learning approach for early childhood education. One of the approaches is BCCT (Beyond Center Circle Time) or well known as center approach.

BCCT approach is convinced to stimulate all students' intelligences (multiple intelligences) through directed games. Setting of learning is able to stimulate them to be active, creative and keep on thinking by gaining their experiences. The learning process goes naturally, it means that students are experiencing, not transferring knowledge from the teachers. Students know what the learning is, its benefit and how to achieve it. Teachers take role as facilitators, motivators and dynamist people. This concept is different from the conventional approach which emphasized teachers learning center; where teachers' roles are more active than students, so students as the only learning objects and teachers as learning sources.

Many researchers suggest that the connection of students' influences is the concept and perception to their friends. Because of interaction between teachers and students is the key in early childhood education process, the diverse understanding of teachers and students' contact is very important to create better future of early childhood education.

The research done by Jelena Spasojevic (2007) on her research entitled "Teacher-Child Interactions in A Prescholl in Serbia" states that quality results of the interactions between students and teachers have become major priority for many researchers and early childhood educators. There has general consensus if overall results from early 
childhood education/preschool depend on the quality between teachers and students.

Dunn (2008) in the research entitled "Impact of Learning-Style Instructional Strategies on Students' chievement and Attitudes: Perceptions of Educators in Diverse Institutions. This research discusses the instructional strategy impact applied by teachers toward students' achievement attitude. The discussed strategies include teaching practice, process of creating syllabus, and motivational values to get good achievement. In this research will be conducted research of whether instructional strategies are able to improve students' perception toward their learning results and whether those strategies can give contribution to educational profession.

Logue (2007)'s research entitled “Early Childhood Learning Standard: Tools for Promoting Social and Academic Succes in Kinderganten" of the manual education standard for early childhood. It states that learning standard for early childhood is arranged to pull together and to build, to achieve K-13 education (2013 Curricullum; which is identified as needed knowledge and skills to prepare early childhood students to study at school and give them supporting facilities in order to achieve social, emotional, physic and inttellegence' successfulness) is the recources benefits which has not apllied yet for educatots/teachers and social practitioners and also kindergarten' students.

In the research which is done by Samad (2016: 1) entitled "Metode Beyond Center and Circle Time (BCCT) dalam upaya penanaman nilai- 
nilai agama Islam di kelompok B TK Kholifah Kota Ternate” (Beyond Center and Circle Time (BCCT) Method in Order to Give the Islamic Values in B Group of Kholifah Kindergarten Ternate). The results show that giving Islamic values have not been done by all parts yet. Then, BCCT learning needs to right management, so BCCT learning could be successful according to the specific standard.

Kindergarten of Bina Citra Cendekia (BCC) Ungaran, Semarang Regency is one of the institutions which used BBCT learning approach. That kindergarten has been applied learning approach since 2011 and has wide enough area to play games and learning area which consists of seven centers along with supported clasess by using AC and also the environment is clear and fresh, comfortable and good quality human resources (stakeholders of teachers). But these conditions (enough facilities and good human resources/teachers' stakeholders) still need to have management or monitoring to support the realization of learning BCCT approach. The intention of the management in this research is learning strategy, learning process and learning evaluation which applied by teachers.

According to that thought, the researchers state the problems 1) how BCCT (Beyond Center and Circle Time) learning management of Islamic education materials applied for early childhood. 2) What are the supporting and unsupporting factors of BCCT (Beyond Center and Circle Time) learning management of Islamic education materials for early childhood. By knowing the intention of BCCT (Beyond Center and Circle Time) learning management of Islamic education materials for 
early childhood, supporting and unsupporting factors. This research is aimed to make learning management on planning, actuating and evaluating runs effectively and efficiently.

\section{Method of Collecting Data}

This research uses qualitative by descriptive approach. Because of the data are words or pictures from interview scripts, field notes, personal documentation (Moleong, 2002: 11). The center agenda of the research is to know some problems related to BCCT (Beyond Center and Circle Time) learning management in BCC Ungaran Kindergarten, so the subjects of this research are the principal, teachers and students in BCC Ungaran Kindergarten.

Then the research method used is non interactive method (Goetz, Comte, 1984: 14). The method is: interview, observation and documentation. The data examiner validation in this research is triangulation. Triangulation in this research is data sources, by: 1) Comparing the results of observation from many parts engaged in BCCT (Beyond Center and Circle Time) learning management by the results of interview. 2) Comparing by what people said in local places personally from the research subject, not only key informant but also supporting informant. 3) Comparing the results of interview by filling a BBCT (Beyond Center and Circle Time) learning management document in Ungaran BCC Kindergarten. The analysis of this research uses explorative descriptive-analysis. Then, data interpretation's plot in this research uses theory comes from Miles, Huberman (1992: 16); data 
reduction, data interpretation and verification. To know more of three components in this research' steps, it can be seen from picture below:

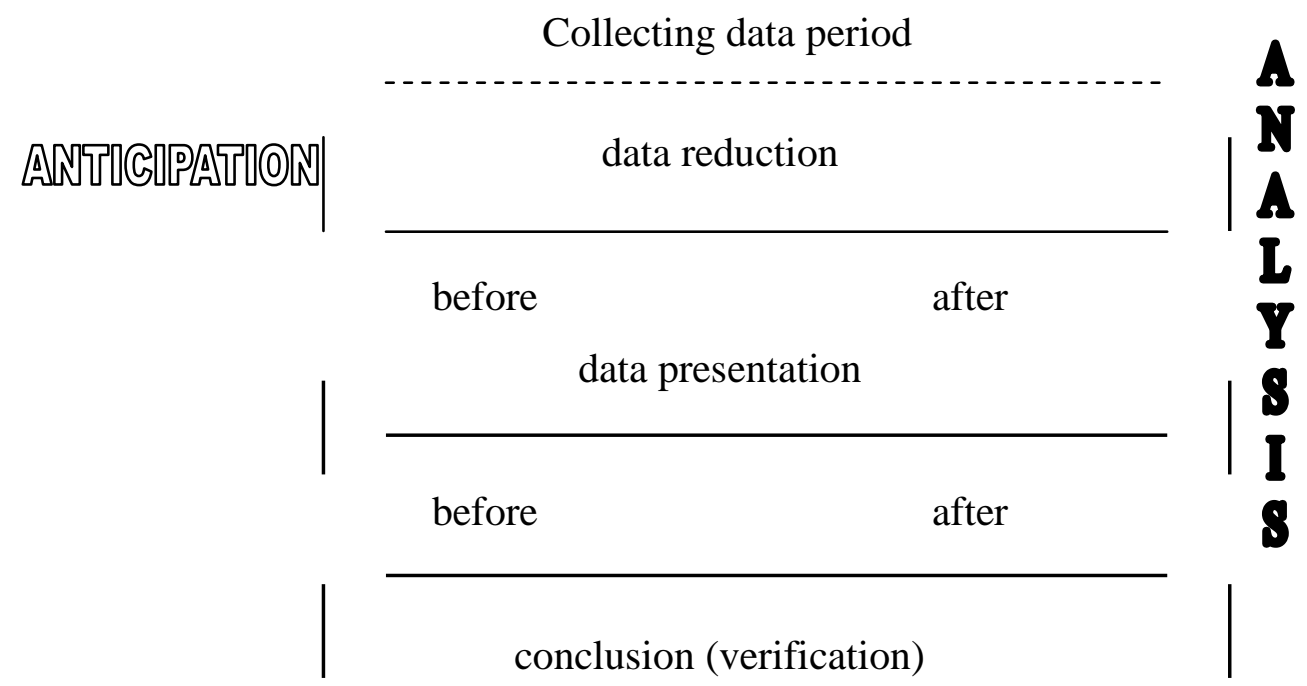

Picture 1. Data analysis steps, Miles and Huberman (1984: 19)

\section{Discussion}

\section{BCCT Learning Management}

The word "management" literally comes from the word "to manage" which is synonym with the word "to hand, to control, to guide" means to manage, to examine, to lead. Then, the terminology term of management meant as continually process that has abilities and special skills by one to do an activity not only individually but also generally to coordinate and use all sources in order to achieve the objective of productive, effective and efficient organization (Engkosworo, Komariah, 2010: 87). Then, learning is interactional process among teachers/educators, students and 
learning sources in a learning environment (UU Sisdiknas no. 2 Year 2003: 5). So, it can be understood that learning management is human resources (stakeholders) management effort included planning, actuating, evaluating, and monitoring to create condusive conditions of teaching and learning. The function of learning management according to George R. Terry, there are four: planning, organizing, actuating (Daryanto, 2013: 47).

Beyond Center Circle Time learning concept is guidance and teachers' hand-work, which is well composed to give choosen materials by using learning method of organized games in some activities and also work procedures. According to Latif, et al. (2013: 88), the kinds of learning concepts are lesson plan for one year, lesson plan for one semester, lesson plan for one month, and daily lesson plan. The principle of lesson plan is: 1) Concerning the level of growth, need, interest and students' characteristics; 2) Integrating the quality of education, care and protection; 3) Actuating learning by games; 4) Learning activity is applied step by step, continually and behaviourly; 5) Learning process is active, creative, effective and glorious; 6) Learning process is centered to the students.

The actuating of Islamic education's material in BCCT (Beyond Center and Circle Time) learning includes the arrangement of playing games' environment and the organizational activity. In Permendiknas No. 58 year 2009 states that 1) Arrangement of games environment to early childhood includes: creating comfortable games conditions, clean, healthy and cozy by using educative games tools which should be safety 
and healthy standard, and based on the stimulation functional program and to get the benefits from environment; 2) Organizing the activity which should be actuated, there are: the activity is actuated in the classroom and the outside of classroom; the activity is actuated in a cozy condition, the activity for 0-2 years old is individually; the arrangement of learning activity to students $2-<4$ years old is in big group, small group, and individual included content and closing activity; the arrangement of learning activity to students $4<6$ years old is applied by individual, small group, and big group consist of three main agenda, there are introduction, contents, and closing activity; engaged parents or families.

Learning by center and circle time approach is early childhood education's approach focused on students. The actuating of circle learning is in the center of playing games and when children are in the circle by using four steps. The step is changed supporting factor which is adapted by students' growth development. Then, there are four steps to support students' development as follow: 1) Environment playing games' step; 2) Step during playing games; 3) When playing games' step; 4) After playing games' step. The kinds of playing games center as follow: 1) Preparation Center; 2) Block Center; 3) Big Playing Role Center; 4) Small Playing Role Center; 5) Natural Material Center; 6) Art Center; 7) Faith center, the description as follows;

Preparation center is a work center and giving the opportunity for students to develop their cognitive, motoric and organized literal cases by teachers and focusing on match, reading and writing 
activities. This center focuses on students' opportunity to make in order, clarify, make patterns and organize games' tools and work's material including reading, writing and counting preparation. Examples: students make in order the small number to the big one, or conversely, arrange small things to big one or conversely.

The preparation center has roles that consist of two different roles. There are work procedure and playing procedure. Work procedure as follows: choosing one work, working until finish, showing the work results, putting the things to the right order, choosing another work. Then playing procedure is love each other, listening, focusing, controlling, using games appropiatelly, sharing- games, still standing in walking team, doing start-finish, solving the problems orally. Games tools in this center are; games tools for supporting the clarificational prosess, ordering, masuring the relationship among mosaic, checkers, chinese chequer, art school, geometric board, pair of scales, puzzle, counting; book, work card, letters card; motoric supporting skills such as many sizes of clips, scissors, papers and steplers, beads and ropes, drawing tools. Preparation activities in this center are reading, writing, and studying mathematics.

Block center is a center which gives the opportunity for students to build thinking systematic ability by using structured development media. This center is aimed to help students to increase their constructional abilities from arranging straight line-to go up to be real representation and from playing by herself to work's ability into small group, planning, and development. The game rules for playing block are 
to build, to build block above board, to collect enough blocks, to startfinish, to play games on time, to put thing in the right order. Playing this block is very useful to develop students' relationship skills to their friends, mathematics concept and geometric, symbolic thought, mind mapping and get skills for comparing the vision.

Block games tools center is supported by many different sizes blocks amount 100-200 natural blocks, supporting tools such as human dolls, traffic lights, and vehicles, board for playing blocks with many forms and colored by primar ink, literation, HVS papers size, crayon, 24colour pencils, pencils, erasers, ruler size $30 \mathrm{~cm}, 60 \mathrm{~cm}$, gauges, and scissors, decorated small size blocks. The activities in block center are; building figures/furnitures by using many size blocks, drawing the buildings which are created by them, playing roles by using supporting tools in those buildings.

Playing big role center is a center that gives opportunity for students to develop the understanding about environment, language ability, getting skills to take point of view and empaty through role playing that create students' knowledge. The aim of playing big role center is to develop social and language interaction's ability, and improve empaty, take point of view of special affection. The rule of big playing role center is to focus on playing role based on the role itself, self control to make interaction with other roles and using tools, putting in the right places/order after playing,. Big playing center is very useful for supporting students to get right ability to separate between activity and game, having ability to keep on feeling then arranging directing action 
flexibility and intentionally, having ability to differentiate between imagination and reality.

The games equipment in big center playing is real sized tool, it means that the games equipment are divided into; household's tools, profession's tools, alphabets' tools. The activity in big playing role center is playing roles which are close to students, such as role as mother, father, doctor and animal.

Small playing role center is giving materials to students through small sized tools. Students act as puppeteers to play dools. The objective of small role center is to build the abstract ability and think objectively, and develop the ability in social and communication interaction. The rule in small playing role as follows; focus on playing role based on choosen dools, self control with other players (students) when using games tools, putting the things in the right order. Small playing role center is very benefit to support students gaining ability to separate their mind from activity, the ability to keep feeling, to arrange directed action intentionally and flexibility, and to have objective though ability.

The games equipment in small playing role center is using games tools or small sized tools such as human and animals dolls, houses furnitures, car figures, trees, boats and planes. The equipment in small playing role can be classified such as mini mockup followed by its proporsional furniture; houses, dolls, tables, chairs which close to houses furnitures' size, human and animals dolls, cooking utensils, professions realted to its roles and alphabet tools. The activity here is to play roles aroud students' world through small size equipment like dolls which are 
taken role as mother, father, brother, young brother, or animal.

Natural material center is a center which gives students' opportunity to make live interaction with many supporting materials such as motoric sensor, self control and science. This center is aimed to give occasion to build abilities by some materials or different materials, give students' opportunity to gain rich motoric- sensoric experience, and build students' control. Then the rules in natural material are using equipment based on its function, self control, putting in the right order, working until finish. The benefits of natural materials are to support every single student' sensomotoric development, support science concept, support students to control more, strengthen the motoric skills.

The games equipment in this center is plydough, finger painting, drawing/painting paint, rice, seed, sand and water, crayon, board maker, painting paper, drawing, finger painting, small brush for painting, meting tool. The activities in this center are the liquid build activity which usually uses fluid materials, such as: water, sand, seed, wheat, meting/measure activity, filling activity; exploring on science knowledge.

Art center is a center which gives students' opportunity to develop their abilities in using and making interaction by using some equipment and materials such as: glue, scissor, crayon, paint, clay, playdough. The objective of this center is to give quality work process experience, this activity does not produce art work, but students will get the happiness from colour' exploration, motoric skills, soft and creativity process, build basic art skills. The rule of this centeri is choosing the provided activity, starting and finishing choosen activity, working by 
creativity, reporting the work that has been finished, changing other art activities, if they have enough time, they will put the things in the right order. The benefits of this center are; developing soft motoric skills, having ability to use materials, having aesthetics ability toward work art, having ability to respect self-art's work and other art's work, and systematically work.

The games equipment in this center is many size crayons and board makers, water paints, small and big brushes, starch/wheat colours, second-materials, kinds clothes, kinds of threads. And the activity in this center is drawing by using crayon, painting by using small/big brush, cutting and sticking pattern/picture, mosaics, finger painting, working art with original or second-hand materials.

Faith center is a center which gives students' opportunity of learning values, religion's rules so that students can develop their belief and pious mind through daily activities especially when they play games. This center focuses on supporting students to recognize and build the concepts based on Al-Qur'an and Hadis. This center is aimed to give students' opportunity to play games equipment through activity in order to choose their own way and use real equipment. Also building self concept as moslem. The rules in this center are how to focus and devout, chose games equipment, put in the right order and well regulated. Then the benefits of this center are students will be happy and love their religion (Islam), so they will perform His regulation sincerely, students are able to perform good behavior like prophet Muhammad SAW taught, students can practice directly of right praying, students get Al-Qur'an 
concept according to students' growth level, students can study, recite and write hijaiyah (Arabic font) correctly.

Games equipment in this center is prayer utensils, Al-Qur'an and Iqra' book (book's module on how to recite Al-Qur'an), hijaiyah car figures, mosque puzzle, ka'bah puzzle, prayer and wudhu (ritual ablution) puzzle, and hajj, plydough, drawing and writing utensil, mark by using hijaiyah stemp, scissor, many paper sizes, stepler, flannel materials based on the theme. And this center's activity discusses about Al-Qur'an verses related to the theme, reciting short verse in Al-Qur'an and daily prayer, reciting and writing hijaiyah font based on students' growth, wudhu and prayer' practise, recognizing the concept of pillar of Islam and iman (faith).

Learning evaluation is a collecting and processing the information to determine students' achievement level includes type of evaluation technique, evaluation process, results process and further action. In the development evaluation's discussion, teachers can recite from language students' performances naturally when students go to school until time for coming back.

That evaluation can be collected from: 1) Students' results, such as drawing results, painting results from art center, building results of blocks come from block center,and create mini car figures from car figures' board box in natural center. 2) Teachers observed's notes of students' natural language, such as body movement in body movement center when students can kick ball quickly, getting assessment from their vocal in prayer center; students can recite Al-Fatihah verse fluency, 
getting assessment from their writing in $\mathrm{ABC}$ preparation; students are able to write alphabet from A-Z, from art ceter; students can draw with many kinds of lines, straight line, oblique line, curved line and zig zag's line that represent their domain of thinking development level. The evaluation of learning center is actuated since learning happens, teachers make note of what activity happens, not only activity program but also students' development. Teachers' notes can be used as input materials in evaluation every semester. Students' development results are reported to parents written and spoken by narration rapport.

\section{Islamic Education Materials in Early Childhood}

Islamic Education Material in Early Childhood Education's curriculum integrated with Islamic values as follows:

\section{Aqidah (Good Behaviour) Education}

Islam puts education in foundation position, it means that Islam is put on the first pillar and as a key to differentiate between moslem and non moslem (Halim, 2001: 95). The discussion of aqidah usually talks about six pillars. Namely believe in Allah, believe in His angels, believe in His holy books, believe in His Messengers, believe in Judgement Day and believe in His Qodlo and Qodar (His determination). Faith/belief education ties students by Islamic foundation, pillar of Islam and syari'ah (Islamic rules) foundation since students recognize and understand things (Ulwan, 2002: 51). It states in holy Qur'an, that has meaning:

"And remember when Luqman said to his child (son) when he gave lesson to him: "hi my son, do not you confederate Allah, confederating Allah is really big sin" (Al-Luqman: 13) 
In aqidah education materials which are taught to early childhood students as follow: 1) Recognize Allah and His creatures, 2) Recognize

angels and the duties, 3) Recite two syahadat sentences, 4) Recognize AlQur'an and Hadist as Islamic foundation.

\section{Praying Education}

The entirely prayer rules as stated on Islamic yurisprudence (fiqh) should be recognized as early as and be students' behaviour. It must to be actuated in order to make students keep in faith; obligate His rules and also keep far away from His ban (Halim, 2001: 102). The things which are taught to early childhood to perform prayer is by making prayer as their habit, praying education is very important given to early childhood to optimalize sudents' development and fill their characteristics as unique individual and different from each other toward their knowledge, experience or skills. Then praying education as follows: teaching fasting, trying to recite the Holy Qur'an, paying zakat, introducing Idul Fitri and Idul Adha.

\section{Akhlak (Good Behaviour) Education}

Akhlak education for early childhood is divided into two parts, they are: 1) Good akhlak includes; honesty, sincere, generous, help each other, kindness and others, 2) Bad akhlak includes; arrogant, stealing, hurt each other, lie, rogue and others. Attitude given to students are directly and indirectly. Directly habits such as habituate students to shake their hands when go to school, praying when they eat, good at speaking, honest habit, love each other, good behavior and others. Indirectly habits such as telling stories found in Al-Qur'an of Prophets' excemplary. 


\section{BCCT Islamic Education Learning Management for Early Childhood}

\section{Lesson Plan}

Before teaching, teachers make lesson plan which has been consultated directly to Kindergarten's principal and asked her approval of her 'yes or no', although there is a curriculum's coordinator. Teachers who do not have experience and knowledge of BCCT, they should be conducted training in Istiqlal, Jakarta and Bandung so that they will get comprehend skills and understanding of BCCT teaching's model by free charge (paid the institution).

\section{Implementation of Learning}

In the implementation of learning, steps that should teachers do as follow: 1) Open the faith center continually based on students' readiness and other supporting facilities; 2) Rotate every group to play in faith center accordance the schedule; 3) Give variation and enough opportunity to every student so they will not get bored and fight; 4) Along with the readiness of learning and supporting facility, add new center if uncompleted; 5) Complete the center of faith with many kinds of educative props made in factory or self-developed with waste/secondhand materials and surrounding environment.

The activities which are performed in learning practice are welcoming students. Teachers welcome students in front of the gate friendly and cheerly by expressing salam (Islamic regard), and ask their conditions and also ask their nike names respectly. Teachers start the activity by praying together. Then teachers ask students to sing, dance, 
jump and laugh, also give applause and wave hands. Teachers ask students to go to games center/playing center with singing together. Teachers here explain games that will be performed by students and make games rule based on students' agreement before games start.

Main activity in every group belongs to three stages: a) Experience stage before playing; b) Students experience stage every student; c) Experience stage after playing; d) Eating the packed meal together. Eating the packed meal which brought every student is actuated during 15 minutes before activity ends. e) Final playing activity. When final activity ends, teachers congratulate to all students of what happened to them. Students pray together and wait for them until their parents pick them out.

\section{Learning Evaluation}

Learning evaluation is held systematically structured with notes record from teachers. Evaluation technique used here is observation, then evaluated aspects include: cognitive, affective, and pshycomotoric. Then the formation of evaluation results is alphabetic and narrative. Parents or guardians are invited to attend students' evaluation agenda every month. It is aimed to give information of students' development in learning process to their parents/guardians.

\section{Supporting and Unsupporting factors of BCCT Learning Management}

In learning process there are some supporting and unsupporting factors on learning implementation, Islamic education material of BCCT 
Learning management has some factors, there are: 1) Bachelor degree qualified teachers; 2) Giving reward for the best teachers from institution such as free training/workshop for intership program of BCC's learning during one week in Istiqlal, Jakarta and all accommodation is free charge (borne by institution); 3) Teachers creativity and spirit conducting BCCT learning; 4) Harmonyc and good cooperation between institution and committee, students guardian/parents and public figures so that it will make good conditions in applying BCCT management.

Unsupporting factors of BCCT learning management in early childhood are: 1) The number of teachers is still limited, so they could not fulfill needs toward the number of students. The comparative ratio of 10 teachers and 20 students x 6 classes. A few teachers still graduate from Senior High School, they are 3 of 10 teachers in BCC Kindegarten then the number of classes is 6;2) Playing games are still limited, it is mentioned at the table below; 3) Media are also limited, so learning activity is not maximal. The average of Childhood Education Institutions belongs to foundation or non-government which does not have permanent donors from society. It means that the institutions are independent. Those factors can be illustrated as follow. The number of teachers is still limited so they could not fulfill students' need toward the number of students.

Table 1. Teachers' position of BCC Ungaran kindergarten

\begin{tabular}{cll}
\hline No & \multicolumn{1}{c}{ Name } & \multicolumn{1}{c}{ Position } \\
\hline 1 & Rachmi Amalya Chomsiaty, S.Pd & Kindergarten's principal \\
2 & Supiyati, S.Pd.AUD & Teacher of B2 \\
\hline
\end{tabular}




\begin{tabular}{lll}
\hline 3 & Choiriyah Ulfah, S.Pd,M.Pd & Teacher of B1 \\
4 & Siti Hartati, S.Pd.AUD & Teacher of B3 \\
S & Yuni Hartati & Teacher of B1 \\
6 & Ngatinah, A.Md & Teacher of A3 \\
7 & Sulistiyani, S.Pd & Teacher of A1 (coordinator \\
& & of curriculum) \\
\hline
\end{tabular}

The condition of playing games facilities is still limited toward the number of students.

Table 2. Playing games facilities' condition

\begin{tabular}{|c|c|c|}
\hline No & Name & Amount \\
\hline 1 & Swing & 1unit \\
\hline 2 & Slide & 1unit \\
\hline 3 & Seesaw & 1unit \\
\hline 4 & Multi ladder & 1unit \\
\hline 5 & Climbing board & 1unit \\
\hline 6 & Big cup figure & 1unit \\
\hline 7 & Swimming pool & 1unit \\
\hline 8 & Jump-squirrel & 1unit \\
\hline
\end{tabular}

4). The average of childhood education institutions is non government or belonging to the foundation which does not have permanent donor yet, all effort are dependent.

Tabel 3. The conditions of learning media in bcc kindergarten

\begin{tabular}{lll}
\hline No & \multicolumn{1}{c}{ Name } & Amount \\
\hline 1 & Television & 1 unit \\
2 & DVD player & 1 unit \\
3 & Tape Recorder & 1 unit \\
4 & LCD & 1 unit \\
5 & Computer & 1 unit \\
\hline
\end{tabular}


Learning media are still limited so learning activities are not maximal enough because the kindergarten does not have permanent donor and it is still independent institution.

Unsupporting and supporting factors of BCCT learning management stated by Cahyowati (2012: 10) as follow: 1) Limited facilities; 2) Less understanding of BCCT happen to teachers; 3) Less of funding; 4) Limited learning facilities; 5) Poor parents' attention in order to support students' learning process; 6) Related support from the institution.

\section{Conclusion}

Islamic education material of BCCT learning management on early childhood is actuated based on Permendiknas No. 58 year 2009 of Early Childhood standard which states that one of standard in actuatating learning is planning, actuating, and evaluation of learning that applied figuratively based on skills, interest and students' need.

BCCT learning process can be actuated clearly if it is supported by quality and quantity stakeholder (human resources) based on childhood's need, facilities, founding and spirit or motivation not only come from internal but also external institution along with good cooperation between related parts.

\section{References}

Abdullah, N. U. (2002). Pendidikan Anak dalam Islam (terjemahan) Jakarta: Pustaka Alamin.

Abdul, H.l. (2001). Anak Sholeh Dambaan Keluarga. Yogyakarta: Mitra 
Pustaka.

Bogdan \& Biklen. (1982). Qualitative Research for Education: An Introduction to Theory and Methods. Boston: Allyn and Bacon .Inc.

Daryanto. (2013). Administrasi dan Manajemen Sekolah untuk Mahasiswa, Guru dan Peserta Kuliah Administrasi Pendidikan. Jakarta: Rineka Cipta.

Dunn, et al. ( 2008). Impact of Learning-Style Instructional Strategies on Students Achievement and Attitudes: erceptions of Educators in Diverse Institutions. The Clearing House. Journal of Education. Vol 1 No 1. Pg: 1-10.

Dwi, C. N. (2012). Skripsi tentang Implementasi BBCT di TK Aisiyah di Jogosuran Surakarta. Solo: UMS.

Engkosworo. (2010). Administrasi Pendidikan. Bandung: Alfabeta.

Huberman, M. (1992). Analisis Data Kualitatif: Buku Sumber Tentang Metode-Metode Baru.Terj. Tjejep Rohendi. Jakarta: UI Press.

Logue, M. E. (2007). Early Childhood Learning Standards: Tools for Promoting Social and Academic Success in Kindergarten.Children \& Schools; Jan 2007; 29, 1; Pro Quest Education Journals. pg. 35.

Latif, M. et al. (2013).Orientasi Baru Pendidikan Anak Usia Dini: Teori dan Aplikasi. Jakarta: Kencana.

Moleong, J. L. (2009). Metodologi Penelitian Kualitatif. Bandung: Remaja Rosdakarya.

Nazir, Moch.(1999). Metode Penelitian. Jakarta: Galia Indonesia.

Otib, S.H. (2000). Metode Pengebangan Moral dan Nilai- nilai Agama. Jakarta: Universitas Terbuka.

Permendiknas No. 58 Year 2009 of Early Childhood Education.

Samad, F. (2016). Implementasi Metode Beyond Center And Circle Time (BCCT) dalam Upaya Penanaman Nilai-nilai Agama Islam di Kelompok B TK Kholifah Kota Ternate. Volume 10 No.2. 
Mudarrisa: Jurnal Kajian Pendidikan Islam, Vol. 9, No. 1, 2017: 28-52

Sutopo, H. B. (2006). Metode Penelitian Kualitatif: Teori dan Aplikasinya dalam Penelitian.Surakarta: Sebelas Maret University Press.

Sujono, Y. N. (2009). Konsep Dasar Pendidikan Anak Usia Dini. Jakarta: PT Indeks.

Sumardjoko, B. (2002). Metodologi Penelitian Kualitatif. Surakarta: Program Pascasarjana Universitas Muhammadiyah Surakarta.

UU Sisdiknas No. 20 Tahun 2003 of Early Childhood Education. 